Portland State University

PDXScholar

\title{
De-Stigmatizing Mental Health Through First Person Narration in Young Adult Literature
}

Tatum E. Francis

Portland State University

Follow this and additional works at: https://pdxscholar.library.pdx.edu/honorstheses

Part of the Children's and Young Adult Literature Commons, and the Mental and Social Health Commons

Let us know how access to this document benefits you.

\section{Recommended Citation}

Francis, Tatum E., "De-Stigmatizing Mental Health Through First Person Narration in Young Adult Literature" (2020). University Honors Theses. Paper 878.

https://doi.org/10.15760/honors.899

This Thesis is brought to you for free and open access. It has been accepted for inclusion in University Honors Theses by an authorized administrator of PDXScholar. Please contact us if we can make this document more accessible: pdxscholar@pdx.edu. 
De-Stigmatizing Mental Health Through First Person Narration in Young Adult

\author{
Literature
}

by

Tatum Francis

An undergraduate honors thesis submitted in partial fulfillment of the requirements for the degree of Bachelor of Arts

in

University Honors

and

English

Thesis Advisor

Gabriel Urza

Portland State University

2020 


\begin{abstract}
This thesis project includes a written short story titled "Quiet Dissonance" that explicitly depicts anxiety and depression within the genre of Young Adult literature. The purpose of this story is to consciously de-stigmatize the mental health issues by depicting these mental disorders as authentically as possible with both research and my own real-life experience of being diagnosed with both anxiety and depression, rather than relying upon stereotypes and the influence of the media. This story is consciously written through the point of view of first person narration, allowing for further exploration into the interiority of the thoughts of the protagonist as they struggle with the reality of their mental health issues versus how they are presenting themselves to the people around them.
\end{abstract}




\section{Quiet Dissonance}

I groaned as I looked over my to-do list for the day. Take medication: already did. Take photos: nope. Do breathing exercises: sort of. Talk to Cassidy: text sent. Eat lunch and breakfast: I had some macaroni and cheese for lunch. Take shower: maybe tomorrow. I finally exited out of the app in defeat, glaring at the time that read 4:42 PM at the top of the screen. Ignoring the reality check, my eyes wandered towards my bedroom window. Sun was shining down on the flower beds in our backyard, my mom's tulips bursting in bright pinks and yellows. Huffing at the scene, I turned away, knowing perfectly well that I could be taking photos right now. Laurel's words echoed in my head: "It's good to get back into the practice of doing your hobbies, even if it feels impossible at the moment. Remember: one step at a time, blah, blah, blah.” Closing my eyes, I breathed in and breathed out. I supposed taking pictures inside was still taking pictures. I searched my wall of photos for inspiration, which covered anything from moments of hanging out with Cassidy, to random objects I found aesthetically pleasing like the vintage clock that was sandwiched between a shot of mom's profile as she leaned over the porch railing, and a typical instagram shot of the Chinese lunch I had after my first therapy session. Acting on impulse, I grabbed my camera and snapped a photo of the neat rows across the wall. Staring at my camera screen, I scowled. Wow, Ashlyn, you can think of something more clever than that.

My window groaned in protest as I struggled to get it open, the glass pane shaking for a moment. Finally, I was rewarded with fresh air and the smell of cut grass, the chirps of birds coming from distant trees. Zooming in my camera lens, I focused on the tulips, my vantage point 
showing just how carried away mom had gotten in planting them. Resting back against the ledge, anxiety loosened its hold on my frazzled nerves, and I breathed a sigh of relief. There. One task done. One step at a time, just like Laurel said.

The sound of a car parking announced my dad's arrival home from work, and I dashed downstairs, grateful for a distraction. The habitual clanging of keys against the bowl on the entry table met my ears as I reached the living room, pushing brown strands of hair out of my eyes.

"Hey, sweetie. Get some fresh air today?"

"Not today," I said, rocking back on my heels. I tugged on the hair tie on my wrist as he wrinkled his nose. His hazel eyes pierced through me.

"It's already 5:00 PM. I know it's spring break, but you ought to be doing something, sweetie."

My nerves were spring coils, tightening with every disapproving line in my father's face, and I flinched as the hair tie snapped back against my skin. "I took some photos. I guess I'm just running out of ideas for inspiration."

“Ashlyn, there's a whole world out there. You used to take so many hikes searching for the perfect shots. Half of spring break is gone now, and you've been cramped up inside all day everyday. Look at you, you're still in pajamas. Call Cassidy at least, do something! Maybe getting you to see Dr. Cagley was a bad idea if you're not making any progress."

"I'm trying, Dad. Really." I could already feel myself being called back to the safe haven of my bed, suddenly feeling drained from this conversation.

"I hope so, Ash. I really do." He sighed and turned away from me, his heavy steps thumping towards the kitchen. Rubbing my wrist, I slid off my hair tie and quickly put my hair 
up before retreating back to my room. Reaching my bed, I flopped down, my stomach a hive of frenzied bees. I thought he understood that I was trying, really trying to work through everything. My bottles of anxiety and depression meds stared at me accusingly from my nightstand, and I rolled over towards the wall, admitting defeat. Nestled in my blankets over break, college applications and expectations from teachers and family who expected me to figure out what I wanted to do with my life in just three short months all seemed less immediate. The truth was, I had no idea what I wanted to do. Dad wanted me to follow in his footsteps, and go into editing and publishing, saying that I could be a photo editor or something. I didn't even know if I just wanted to study photography. Having my photos all to myself felt safe, like I had something I could escape into when I had the energy for it. Right now, my escape was my bed. In the past, I would have occasional blips where I would just cocoon myself in my room for a few days, barely dredging up the energy for just doing homework. It was easy to ignore; mom would call these my "bear days," when I would have mini hibernation sessions. But now, these "sessions" didn’t seem to end anymore, my mind sluggish like molasses.

The loud chime of my phone disturbed the quiet of my room, my limbs startling in response. Chastising myself, I grabbed it, happy to be released from my thoughts. Cassidy's name lit up the screen.

Cassidy: "Hey girl, sorry I didn’t get ur text."

"Was out rock climbing with my brother!" My stomach tied itself in knots as I stared at my screen. Of course, she was able to stay carefree during break, no problem.

Me: "No worries! Sounds fun! Who made it the highest?"

Cassidy: "Umm me, duh! How'd you do with ur list today?" 
Me: "No dice. Still in a funk." I sighed. That had to be the understatement of the century. Cassidy: "I get that. Let's hang out soon?"

Me: "Maybe. Have been super busy with taking photos."

Cassidy: "Send me some of the pics!"

I stared hopelessly at my screen, at a loss for a response. Guilt ate away at me like a dog with a bone, and I knew that I would have to come clean with Cassidy when we got back to school. She thought that the break was helping, which couldn't be farther from the truth. Having more time on my hands meant more time being chained by my thoughts. Taking slow, deep breaths, I closed my eyes, counting to ten. It's okay. Hopefully she'll understand. Right? I just wanted one interaction over break to remain normal without her also being worried about me. It would be fine, I could fix this... just not right now.

I glanced at my laptop, still closed shut like it had been all spring break. I trudged my way over to it, balancing it on my lap as I sunk down on my bed. I tried to stay calm, taking even breaths as I opened the screen, my college application staring me in the face. It was for the University of Oregon, which had a photography program. Though I wasn't sure if I wanted to share my photography yet, it felt comforting knowing that it was an option. Mom had changed her major four times before she finally landed on nursing, so I knew there was time to figure out what I wanted to do, but it still felt like time was slipping through my fingers. It all seemed so abstract and far away, and I couldn't help but feel like everything was piling up on top of me.

I opened my $\mathrm{U}$ of $\mathrm{O}$ application: late deadline. California Institute of Arts: late deadline. Seattle University: late deadline. Every application, I had already missed all of the regular deadlines for submission. The earliest one I had to meet was March 22nd, which was only a 
month away. Having been idle for most of spring break, I knew that I would now have to balance those deadlines with schoolwork as well. Scrubbing my face with my hands, I tried to stay calm. "You're not the only student applying for these deadlines, you know. There are so many others out there, in the same boat as you." Laurel's words did little to comfort me this time, feeling as though I was in the boat to finish last in the race. Frustrated with myself, I snapped my laptop shut, not anywhere closer to completing my applications than I was before. Defeated, I retreated back into the safety of my covers, wishing that I was someone else who knew what they were doing with their life.

Fiddling with my seatbelt strap, I stared out the window. I wondered if mom thought this was all just a waste of time like dad seemed to. Well, at least I would have something to talk about with Laurel.

"You're awfully quiet."

“Just thinking, mom," I grunted, watching the familiar buildings pass us by.

"It worries me when you get lost in your head, like a turtle hiding in its shell."

I glanced at her, watching as the sunlight passed over her brown curls. The roots were starting to gray, and I thought it made her appear more wise, though I knew she would just protest that she was younger than she looks. Her nails resting on the steering wheel were unpainted, and I imagined all the times she would have to scrub her hands at work before attending to the next patient. A thought occurred to me.

“I'm not hiding, just thinking. And why doesn't dad ever drive me to my appointments?" "If you weren't hiding, then you wouldn't change the subject." 
'No, seriously, you work so much later than him, shouldn't he be the one driving me on the weekends, so you can rest?" Or does he really hate the idea of me in therapy so much? I looked away, wincing as my teeth dug into my bottom lip.

"What on earth brought this on? I'm fine, sweetie. Your father and I have already discussed how we would get you to your appointments, and agreed that this was the best way."

“Oh. I was just wondering." I kicked my feet against my seat. Why would they agree that was the best way? Did he really think I was so much of a failure right now that he wouldn't even drive me? I rested my head against the window for the rest of the ride, listening to Hayley Williams sing she was in the business of misery.

"Right! We're here. I hope it goes well, sweetie."

My lips were barbed wires, bending upwards in an unpleasant smile to appease my mother as I grabbed for my bag. "Thanks, mom."

Entering Mindful Matters always felt like I was walking with crashing cymbals, announcing to ongoers on the street my destination. Of course, I knew that going to therapy wasn't anything new, lots of people did it, but somehow it always felt like I was alerting everyone around me with a public service announcement that "My brain is different! Not normal! In need of a doctor! Help wanted!’ As I sat down on the green couch in the waiting room, I shook my head, feeling silly. I've been coming here too long now to be thinking like this — this was just my new normal now.

My thoughts were cut off by the opening of the main entrance door, as a father and his son shuffled into the waiting room, sitting across from me. The boy seemed young-eight at the most - and the dad seemed to be absorbed in his phone, the light from his screen highlighting his 
passive face as he pushed his glasses up his nose. It felt like I was seeing a part of their family life that I wasn't supposed to as I turned my attention back to the closed door leading into the offices. I heard the boy grab one of the coloring books in front of him, his clumsy grasp sending the cup of crayons clattering across the center table. His father said nothing in response, and I couldn't help but wonder what on earth would bring this young boy to a place like this. I've never seen them in this waiting room before, and it felt suffocating, sharing this waiting space with these two strangers, like we were all sharing in on a secret just by being here together. Of course, I knew that the crayons and coloring book on the table meant that Mindful Matters planned for children coming to visits, but it was hard for my mind to come to terms with an actual child, scuffed sneakers and all, to be sitting and waiting for an appointment which could be highly nerve wracking for adults-I could only imagine what that may feel like as a child. Looking down at my own black flats, I couldn't help but feel ashamed of my fascination with this family. It was no business of mine to wonder, and I felt close minded, though why, I wasn't entirely sure. As the boy hummed to himself, my nails were like a wooden spoon used to chastise a child against the skin of my palms as I felt my shoulders tense in defeat. This humming boy seemed to be much more at ease in this space than I did, like this open waiting room was merely the wait before visiting time, whereas to me it felt more like the wait before being put on trial. Because of this, I stiffened, feeling caught when the knob on the door to my right finally turned, and Laurel finally stuck her head out to greet me.

I quickly grabbed my messenger bag, the sun from the front window highlighting the monarch butterflies scattered across its fabric. Following Laurel into her office, I couldn't help but be intimidated by the clicking of her purple heels. As I shut the door behind me, I heard her 
settle in her chair, her foot tapping on the ground. I finally settled on the couch across from her, grabbing a pillow to prop up behind me.

“Well, Ashlyn, it's good to see you again! I hope you've been doing well since I've last seen you. I'm afraid that I might have to cut our appointment short today — my house is undergoing some repairs at the moment, and I have to be there to let the repair people in, unfortunately." I found myself forcing my lips to tug up into a smile like a child forcing the wrong piece into a puzzle slot. As much as I dreaded our appointments, there was something comforting to me about Laurel. Her attentive coffee-brown eyes, though at times seemed like jarring spotlights, were also a reminder that I had a lifeline in someone, and feeling that line suddenly yanked from my grasp and leaving me floundering for breath reminded me just how much I actually rely on her.

“That's fine," I finally responded, hoping that she couldn't tell just how freaked out I was about her announcement. I may be on trial right now, but there was always a sense of control I felt in being able to answer her questions, and like my lifeline, that control was quickly slipping away from me.

“Again, I'm really sorry to have to do that to you, Ashlyn. Let's start by going over how spring break has been so far for you. I think last time I saw you, you were excited to have a reprieve from the demands of your schoolwork." I shrunk back into the couch, dreading the S Word. I couldn't escape it—couldn't find any reprieve from it, not even in the small space of Laurel's office.

"Um... it's been going — alright. I guess that I thought all the strain would go away once break started, but it's still there. I mean, dad and mom still have expectations for me that I hadn't 
thought of, and I just feel like- like I could be doing more, I guess.” As I let out a breath, I watched Laurel's eyes scrunch up in response to my words, and I felt like I said something wrong.

"What do you mean 'do more?" What exactly are your parents expecting of you during spring break, and what is it that you've spent your time doing?"

"Well," I began, waving my hands as I grasped for my words, "I guess I just expected everything to, I don't know, go back to normal? But it didn't, and I feel like I should be going out more, getting my applications done, be taking more photos—like dad wants me to- - but I just feel... deflated, I guess. Like, nothing has happened, so I should be doing fine, but I'm... but I'm not." I winced as I snapped my hair tie against my wrist a bit too hard, my fingers worrying at its loose strands.

Laurel crossed her legs before responding: "I don't think there's a clear divide between 'normal' and 'not normal' like you seem to think there is. You are unfortunately someone that suffers from anxiety and depression, so your "normal" might look more strained than someone else's normal, even if nothing of particular consequence seems to be going on at the moment. Does that make sense? As for your dad, I'm sure it's hard for him to watch his daughter struggle with herself, and that he's hoping that your hobbies and schoolwork will help to bring some sense of comfort and structure to you. I know it's all more complicated than just picking up your camera and suddenly feeling better again, but I can't help but think of my own son, to whom I'm sure I often come across as too overbearing when in reality, I'm just worrying for him, and hoping for the best for him. Where are you right now in your application progress?" 
As Laurel talked, my fingers strayed to my hair tie less and less, and I took a deep breath, expelling some of the tension in me. "Yeah, that makes sense. It's just hard not to use labels like 'normal' and 'not normal,' I guess. And I'm... nowhere closer to being finished with my applications.”

"That's all part of the process of working to rewire how society has taught you to view your own disorders, unfortunately. If not applications, what have you been able to do over break so far?"

"Well..." I thought of the pile of laundry in my room, the nearly stationary camera, the crumple of blankets tossed across my bed. "I've been working more on my lists you wanted me to make. They've helped bring more structure, I think.”

“That's good! I'm glad we've found something that seems to be helping you feel more in control again. I wonder if maybe it would also help you to actually also make lists of things that you wouldn't normally think to. So, like making note of your medications and your class schedules, also actually making plans for things like taking photos for today, or even scheduling in walks or times of the day to work solely on your applications."

I looked down at my flats again, embarrassed. "Actually... I already started doing that a little, with like..." I thought of my notes to shower and to make the bed. "With taking photos, actually. I don't always have the energy to actually do it, but I have been adding more things to my list like that..."

Laurel beamed at me, her warm smile filling me with more confidence than I've felt in nearly a whole week. "That's great, Ashlyn! See, you're making more progress all on your own than you think." I smiled my barbed wire smile at her, thinking of all the times I wrote to do lists 
like "get up, take showers, eat something," only to take refuge in the covers of my blankets for entire days.

I was thrashing underwater, my body dead weight as my limbs desperately pushed upwards towards whatever surface lay above me. Wherever it was, it had to be better than this as I flailed, water fueling the flame in my lungs rather than putting it out. My insides were wire leads as the water consumed me, sending electric shocks throughout my body. I struggled, writhing in place, my limbs continuing to fight for an upwards momentum, and suddenly I was skyrocketing to the surface.

Light assaulted me as I crashed onto solid ground, my body hitting sand with a thud. I could only splutter, trying to cough out the water that was still suffocating me, my lungs now a full on raging wildfire. Water gushed out of my mouth as I continued to cough and flounder, sand grinding deeper and deeper into my knees and finding its way under my nails. As the last of the water left me, I sat, shuddering as the aching of my throat suddenly doubled, and it was all I could do to keep from crying out in pain. On all fours, I looked up, realizing in horror that I was still underwater, the sand suddenly gone from under me. Now, instead of the sea, I was in a tank, unable to see where I was due to all the people pressed up against the glass, watching. I squeezed my eyes shut, pretending that I was back in the sea instead of here on display, my inability to stay afloat captivating an audience who I assumed all knew how to swim perfectly. My arms and legs might as well have been made of stone as I sunk to the murky bottom, giving up all hope of swimming to the surface. Nothing that I did was enough. 
I woke up gasping, and I panicked, scratching at my throat, trying to cough up water that wasn't there. I was in my bed. There was no water. I was completely safe. Knowing this didn't stop my shaking as I struggled to wipe matted strands of hair away from my clammy forehead. Giving up, I pressed my head against my knees, shutting out the green walls of my room. Breathe in. Four seconds. Hold. Seven seconds. Breathe out. Eight seconds. In. Hold. Out. In. Hold. Out. In. Hold. Out. Rather than my lungs burning, I felt my nerves relax as I finished my exercise. I was supposed to be doing this sitting up, but my bent position was all I could manage at the moment, my limbs mere wobbling jelly.

My phone chimed with a text message, and I hunched further into the support of my knees. Not looking up, I grabbed my phone, only lifting my head when I had the screen unlocked with my thumbprint. It was Cassidy: “Srsly missing you! Hang out tomorrow?” Knowing that I couldn't put off responding any longer, I sighed and sent off the text: "Sure, would like to catch up!" That over with, I got up, realizing that it was already 11:00 AM. As I headed out of my room, my phone chimed behind me, and I could only assume that it was an exclamation of excitement from Cassidy. I felt guilty, knowing that I should be happy to see my best friend, but I couldn't summon enough energy to do so. My mind felt sluggish and lethargic, and I just hoped that I wouldn't be put back on trial with questions from mom and dad today.

Reaching the kitchen, I saw dad still sitting at the table and reading the newspaper. I knew he would read it start to finish, but end with the funnies section, which was always his favorite. Every now and then I would snatch the pages with the word searches and sit across from him, sharing in the mundane peacefulness of the moment. I didn't feel like word hunting 
today, and instead grabbed a bowl of cereal, scraping the wooden chair across the floor as I sat down. I could feel my dad's eyes on me as I ate my Cinnamon Toast Crunch.

"Well, look who decided to join us! I was beginning to think you had become a vampire or something."

I scowled, clanking my spoon against my bowl. "No, just tired, I guess. Where's mom?” "Out in the garden. Watering her tulips."

"Do you think she knows that other types of flowers actually exist?"

"When she finds out, let me know, and we can both plan a celebration party for her."

I managed a small tug of my lips in response. "So, I might see Cassidy tomorrow, is that alright?"

“Of course! Glad to hear it, Ash—it'll do you some good to have some interaction outside of your rusty, old parents."

"Har har." I had finished my cereal by then, but I stayed seated, tapping my foot against the brace of the chair legs. Laurel's words floated around in my mind, about my dad probably being more worried than disappointed in me. I wondered if I was really reading too much into everything, tangling my finger in my hair as I tried to think. Resting my foot on the floor, I opened my mouth, ready to ask him — what, I didn't really know. Did he really think I wasn't doing enough? Did he know I was trying to stay afloat as best as I could? My fingers drifted down from my hair, and onto my hair tie, my thumb and index finger brushing against the cold metal part. Bringing my bowl over to the sink, I finally settled on "I'm heading outside," before crossing over to the sliding door. All I heard was a grunt in response. 
I sat on the porch, fiddling with my camera. Cassidy was supposed to come over today and I was trying to be thrilled about it. I knew I should have been more honest with her from the start, but I just wanted to feel like at least one person wasn't looking at me like I was the kid floundering in the shallow area of the pool. Kicking against the step, I looked out at the blossoming trees. Spring has always been my favorite time of the year, when everything was full and bursting with life. Feeling inspired, I grabbed my camera, focusing in on a specific branch, watching a blue jay hopping along, its head twitching from side to side. I had to stand up for a better shot, welcoming the weight of the camera in my hands as my shoulders began to relax, angling my feet as I craned my head upwards. While I could have simply snapped a simple shot, I rejoiced in the dance that was finding the perfect angles, my partner being the subject of my focus. Just as I was about to snap a photo, the blue jay flew off, a flurry of blue and white feathers spotting the sky. Laughter bubbled up in me, and I couldn't help the giggle that escaped out of me. It wasn't the first time a shot had gone awry for me; far from it. I imagined the blue jay flying off to its next mission, thwarting unsuspecting photographers' camera shots.

"I haven't seen that camera in your hands for a while now."

My mother's words startled me out of my reverie. "Was just saying hello to our neighborly blue jay."

“It's getting to be so beautiful out, isn't it? It's been so good for my tulips lately," she replied, wiping dirt onto her capris jeans.

"Right. Your tulips."

“So, I bet you're excited to see Cassidy." I bit my lip. "Or.. not?" 
"I just... feel like I'm letting her down by not being my normal self all the time."

She sat down next to me, patting the area by my feet. "Sit. What's bothering you exactly?"

Complying, I sat down next to her, avoiding her searching gaze. "I don't know, I just.." Her eyes softened and I felt tears wet my eyes. I've been keeping everything bottled up for so long, I didn't know where to start.

"It's okay, sweetie, take your time."

Steadying myself with a deep breath, I looked out at her tulips as I tried to steady myself. Here goes nothing. "She still wants to hang out and talk all the time, but... I just don't always have the energy for it, and I feel like I'm letting her down in some way. I'm supposed to be her best friend, I should be happy to see her." I dared a glance at my mom, trying to discern her expression through the sun in my eyes.

"People have ups and downs all the time, sweetie, it's part of life. I try my best to always be at the top of my performance for my patients, but even I have hiccups sometimes. I'm only human-you're only human."

"But-"

'No matter what you're going through, aren't you still Ashlyn? Isn't she still Cassidy?"

"But it's different."

"It is. But as your friend, I'm sure she would understand and try to be there for you. But it's up to you to determine what exactly you need from her right now, and to communicate that to her. Isn't that fair?" 
I huffed out a breath, amazed at how she always seemed to be able to get to the heart of a problem. Leaning my head against her shoulder, I looked out at the trees lining the fence. "That's fair. Thanks, mom." Closing my eyes, I could feel her ruffle the top of my head, some of her fingers getting stuck in the tangles of my hair.

"But, I do hope that you at least shower before she comes over." I cringed, running a hair through my matted hair. It had been days since I showered, I think.

"Yes, I'll shower." I felt her stance loosen beside me, "I'm sorry that I've made you worry, mom."

"Nonsense, I'm always going to worry, sweetie, it's my job."

"But I haven't told you at all... you help so much with everything, and I just- I just really appreciate it." I turned my head into her shoulder, squeezing my eyes shut, trying not to let any tears spill.

“Thank you, Ashlyn. I'm just trying to do my best, like everyone else. Now go get clean before Cassidy comes over." She kissed the top of my head before getting up, leaving me feeling as content as a cat sleeping on an extra fuzzy blanket. For the first time in days, I got up to go shower.

Breathing deeply in the steam filled bathroom, I realized too late that I had forgotten to take my medication today. I thunked my head against the shower door, frustrated with myself. It was such a little, easy thing — as easy as remembering to eat. Control was quickly slipping through my fingers day after day, each accomplishment being blotted out by twice as many blunders. I was fine. I could do this. It was still just 
break - I could get myself together before school started again. I was fine- this was finewasn't fine- I'm not fine. No amount of fresh cleanliness from my shower was going to ease the growing anxiety thrumming through me like an overcharged circuit. A certain thought kept tugging at the edges of my mind. What if Cassidy couldn't forgive me for being so distant lately? I haven't been entirely honest with her, and she had every right to be upset with me. I was lost in a maze of my own making, each new worry another dead end. She would think I've changed- that I'm just making excuses- that I don't want to be friends anymore- I do want to be friends- it's just all too much right now- all too muchall too much- I'm too much.

Bracing my hands against the counter, I looked in the mirror, hardly recognizing the distant, tired look in my eyes. The brown hair was mine, the dimples were mine, the sharp jaw was mine, but the eyes were foreign, someone else's. I was underwater once again as I tried to maintain control over my breathing, but it was useless as my throat burned and my face and hands quickly became TV static. Hunching over, I grappled with myself, fighting to regain any sense of logic. My head felt like the inside of a balloon as I desperately counted the time. Four seconds. Seven seconds. Eight seconds. In. Hold. Out. In. Hold. Out. My breathing became ragged with every frantic inhale and exhale. In. Hold. Out. In. Hold. Out. Unable to stand upright any longer, I slumped to the ground, grateful for the cool tiled flooring. Long breath in, long breath out. Long breath in. Long breath out. Any energy I had left drained from me as I began to regain a normal pace of breathing. I closed my eyes, feeling as though I had lost the battle despite bringing myself back to the surface. Trying to control my breathing was always a marathon, my 
competitor always being my own thoughts as I tried to jump over each illogical hurdle. It was at least five minutes more before I dared to try and stand again, once again facing off against myself in the mirror. Splashing water against my face, I tried to bring some brightness back into my eyes. I could do this. I was just Ashlyn. And Cassidy was just Cassidy. Medication was as easy as remembering to eat. School wasn't anything I haven't done before. Using the wall to steady myself, I made my way to my room to get dressed. It was time to get ready- I could get ready.

Going to my room, I chose the clothes that most felt like battle armor in that moment, pulling on my pink flowered tank top with a black layered skirt. After pulling my shoulder length hair back with a navy blue headband I searched for my beloved black flats — simultaneously the most comfortable and comforting items I owned. Looking in the mirror above my dresser, I finally felt ready to face Cassidy as I smoothed back the last errant strands of my hair.

“Ashlyn! Cassidy's here!” Right on time, my father's voice cut through the house like my alarm startling me awake in the mornings, reminding me to take my medication before getting ready for the day. Coming into the kitchen, I saw her already settled down, answering my father's queries about how her break has been. Her chestnut hair was pulled up into a ponytail, and her lips were shining with pink lip gloss. She looked much more relaxed than I felt, lounging in a rainbow $\mathrm{t}$-shirt and purple capris pants, her black sandals loosely hanging from her feet, only her tiptoes touching the floor. 
“-Oh, it's been so great- I'm sad to have to go to school tomorrow. I've been helping mom paint the living room— it's all a complete mess at home right now — our dog Mango is so confused about it all-Ash!”

I was immediately engulfed in her warm hug, her body positively thrumming with excitement. I could smell her coconut shampoo as she began to giggle. "Hiya, Cass!"

“I can't believe it's been like a whole week since I've seen you! OMG!"

I couldn't help but smile in response, her buoyant mood anchoring me as I tried to calm my frazzled nerves.

“Cassidy was just telling me about her college plans. Arizona university-I can hardly believe it! Aren’t you looking at colleges closer to home, Ash?”

I shuffled my feet, trying to keep my smile on my face. "Yeah, they're all west coast."

“OMG, you haven't told me if you've been accepted to any yet," Cassidy chimed in.

Heat warmed my cheeks as I looked down at the ground, unable to face any judgements. "Actually, I'm still working on my applications..."

"Oh..."

“Ash is still just taking the time to think about her future. Right, Ash?" I blinked up at my father, surprised at his interjection. I couldn't see any accusations in his eyes, only warmth. Smiling felt a little less forced now. "Yeah, it's taken me awhile to narrow down my list of schools." It wasn't entirely a lie. 
"Well, I'll leave you two girls to it-holler if you need anything!" With my dad's parting remark, we were left alone, and I couldn't help but wish I were wearing a hair tie on my wrist right now.

"I’ve heard so little from you over break, Ash! What have you been doing? Show me all your cool new photos!"

"Well... come out back, I'll show you where I found a blue jay," I replied, relieved that the discussion had strayed from college.

Snatching my camera from the dining room, I led Cassidy to the backyard. I felt calmer out here for some reason, like the open air had some magical quality to its oxygen that I could breathe in, giving me the courage to come clean with Cassidy.

"See that branch over there? On the cherry blossom tree? I found him hopping along there, and this was the best picture I could get, unfortunately." I watched as Cassidy studied the photo, her ponytail framing the left side of her face as she angled her head downwards in concentration. Her olive green eyes shone in the sunlight, and I could imagine her looking at some long lost treasure the same way she was studying my work.

"Even the photos you mess up on turn out interesting. I don't know how you do it, Ash. Did you name him?”

"Name him?” Cassidy was like a life coach, teaching me new tricks as laughter bubbled out of me without my permission for it to do so.

"Yeah, name him. Like, I like to give everything a story- do you do that? I like to imagine where things came from, how they got from point A to point B. It makes 
everything more exciting... more dynamic.” I thought of all the days spent staring at my ceiling, willing my mind to be blank.

"Well, I guess I do that a little with my photographs. What do you think we should call him?"

The tip of her tongue poked out from her mouth as she thought, her fingers twisting strands of her hair. "How about... Hopper. He started hopping the moment he hatched out of his egg, and now he's flying off on his next adventure, determined to hop in every new place he finds as his own discovery ceremony."

“That's-“ I couldn't even finish, her words acting as the caress of a light feather dancing across my rib cage. "That's perfect."

"It is, isn't it?" Her pink lips shined in the light as they stretched into a huge grin, pleased with her own story.

“Cass, I haven't been fine.” It was like I was a puppet with strings attached to my lips, tugging at my mouth to form these words, and Cassidy's confused expression mirrored my own feelings. Where did that come from? It must have been how easy it was to feel comfortable with Cassidy, her brightness expelling any shadows that my anxiety had cast upon my mind.

"What?"

Suddenly overwhelmed with how much I've actually missed Cassidy, I think of all the times she's been there for me, not judging me when I had to go on my medication. The least I could give her in return was my honesty. "I'm sorry, that came out of nowhere- but I think I have to finally say it. I'm- I haven't been doing great like you have 
over spring break. I've been struggling still with my... my mental health. And I just wanted someone to see me as normal, as old Ashlyn again, so I haven't been entirely honest whenever I texted you.." I wrung my hands in place of snapping black elastic against my wrist, my teeth digging into my bottom lip. I could barely look at her, she was so still compared to how lively she's been since she's gotten here. It frightened me. Cassidy was supposed to be as loud and boisterous as a young puppy in its new homenot- not this statue of concern that stood in front of me, tugging on her ponytail now rather than twisting it playfully.

“I mean... I guess I suspected that already, Ash. I'm sorry, but you're just different now and... and whenever you would answer my texts, it was always brief and not really responding, you know? But, that's okay, I mean. I just wish you would open up to me more, so I could help. But, it's okay that you're struggling. You know that, right?"

"I..." I opened my mouth, but nothing would come out, and I desperately tried to hold back the tears springing to my eyes. I thought she would be angry, but she was understanding, which was almost worse. Heat flushed across my cheeks, and I looked away, ashamed. "You're right," I rasped.

"What?"

"You're right," I repeated, clearing my throat. "I should be more open with youyou're my best friend. I was just- scared.” Cassidy smiled in response, which I didn't understand. 
"You look so worried! Did you think this was going to be some big event? That I would accost you about it? Ash, I'm here for you always, but this time I felt that I should wait for you to talk about it when you were ready. Does that make sense?"

"Yeah. Yeah, it does." Dumbfounded, I stared at the warmth in her crinkling eyes. I didn't feel magically lighter at all, like all the worry just suddenly left me. Instead, it was still there, waiting in the background of my mind as I realized that I had given Cassidy less credit than she deserved. So silly, like she said, so stupid. I had been creating a mirage of my life for someone who already understood and saw through all my tricks, knowing me too well for me to successfully pull the wool over their eyes. Unable to hold the tears at bay any longer, I felt snot trickle down from my nose. "I feel so stupid."

Cassidy being Cassidy, she continued to smile. "I mean, it was kind of stupid. Come here.” All I could smell was coconut as her arms held me. She wasn't electric with energy anymore, but rather was a strong dam, holding all of my anxieties at bay. She was completely grounding, and I wished I had just been completely open with her from the start, as I had no doubt in my mind that she would have been just as anchoring then as she was now. "Enough now. Let's go on one of your nature walks."

“Alright," I sniffled in response, thinking of all the time I had spent in bed across the entire break. "Let me head back inside to grab some sneakers."

"Awesome, I'll wait out here and see if I can spot some more friends like Hopper." My replying smile was completely painless, free of any imagined barbed wires. Cassidy and I walked for an hour or so, and she would make silly poses along the wood path as I snapped my photos. The fresh air helped clear my head, and for the first 
time in ages, I felt my worries slip away from me as I got lost in the present. Cassidy left after once more stating her excitement for school tomorrow, and I couldn't help but smile, her mood contagious.

I now found myself on my bed, staring at my $U$ of $\mathrm{O}$ application, spurred on by my dad's earlier comments. The main part I was focused on was the required essay. I wasn't sure what would make me stand out from everyone else- - I was an average student, nothing special. I glanced up at my wall of photos, looking at past memories where Cassidy had also struck a silly pose back then as well. Some things were always a familiar constant. I then looked to the upper left photo, which was of a family outing to the park, where my dad had attracted the attention of a squirrel with his sandwich. Hands hovering over the keyboard, my mind remained blank. What sets me apart? Giving up for the moment, I switched over to my reminders in my phone, setting new alarms, Laurel's advice about lists ringing in my mind. An application for every week. I could do that. I wondered if that would be enough to meet my dad's expectations, though his comment earlier about taking my time with my future gave me hope. Glancing at the clock, I groaned. 10 PM. Time to get ready for bed.

I was in the woods this time, the scratch of branches hitting my skin as I ran past. I was looking for a path- any path that would guide me back to familiar surroundings. My stomach felt like it was filled with sharp needles as I ran, my heartbeat drowning out any noise from any creatures that may live here. My throat was rough sandpaper, and it was 
all I could do not to collapse and try to catch my breath, because I knew if I stopped running, I would be trapped here forever.

As I ran, my eyes darted about, searching for any posts that might be blending in with the trees, for any lettering that might stand out from the nature around me. Thump, thump, thump, went my heartbeat- thump, thump, thump went my feet slapping across the green floor. Only one of my feet were covered - my black flat now caked with brown clumps of dirt, with threads unraveling from the tip of the shoe as my feet continued to get caught on twigs and bushes. My arms were covered in scratches, my left shoulder left bare and bleeding from my torn sweater.

“Ash!" Finally, a sound other than my own heartbeat blessed my ears, a faint call echoing all around me. I spun around, my eyes darting from tree to tree, desperately trying to find the source of the call.

“Ash!" There, ahead of me, the trees grew thinner, I was almost out, I was-" "Ash, this way." Another voice joined in the chorus, and I quickened my pace. It was a male and a female, their voices strangely familiar.

"You're doing great, Ashlyn!” Suddenly blinded by the sunlight, I stopped, panting as I attempted to catch my breath, my lungs running a marathon of their own.

“Don't stop now!" It was now a chorus of three voices, and I glanced around me, searching for any signs of another person having been here before me. I kicked off my remaining flat before finally deciding on walking towards the gap in the trees before me. "Yes! That's it!" "You're-" 
I snapped my eyes open, the calls of my parents and Cassidy receding from my head as my alarm blared. Rubbing my eyes, I sat up, fumbling around for my phone, nearly pulling the charger from the wall socket. I sighed a breath of relief when I finally managed to turn it off, anxiety gnawing away on my insides in response to the angry and persistent beeping of the alarm. I opened up my notes app to look over my to-do list for the day, swiping my medication from my bedside table as I did so. It was the first day back to school; I better begin the day as grounded as possible. After setting down my glass of water back on my bedside table, I sighed, knowing that that was only the first step to getting ready. My arms and legs felt heavy, like I could sink into my blankets and just disappear. I could hear the movements of my father throughout the house, and I was sure he had no trouble leaving his own bed this morning. His morning routine was like clockwork, and he was always sitting at the table fully dressed, hair combed by the time I made it into the kitchen each morning. I glanced at the clock - without my knowing it, twenty minutes had already gone by. I sighed, peeling myself off of my bed.

Showering and finding clothes to wear was just as much of a struggle, and I felt like I should have been eighty instead of eighteen with how slow I was moving that morning. I finally made my way to the kitchen and, as expected, my father was already seated at the table while mom had already left for work. The rustling sound of the newspaper greeted me as I came in, heading straight for the freshly made pot of coffee.

"Big day, big day! Made some coffee for you!"

"Thanks, dad." I opened the cupboard door above the coffee maker, deciding to use my mug with the giant, red rose on it. 
"Excited for school to start again?"

I couldn't help but wrinkle my nose as I stirred my milk into my coffee. "Nooope."

"Well, maybe you'll be surprised. It'll have you moving again, at least."

I winced, my spoon clinking a little too hard against my mug with a loud metallic sound. I inhaled sharply. Now was the moment to ask, and I wished it wasn't, feeling like I was about to climb a set of stairs that had nails sticking out from the floorboards.

"Dad..."

"Yes?" I heard him slurping up his own coffee, the newspaper rustling again as he shifted in his seat.

"Do you think I'm not doing enough somehow? That I'm... failing atsomething?" More rustling and then silence.

"Ashlyn, look at me." I turned around, biting the inside of my cheek. His dark eyes bore into mine, his arm resting against the back of his chair to turn towards me. "I think you're doing phenomenal—no, don't look at me like that. You really are. I know some days are harder than others, and this is going to continue to be a bumpy ride, but I can really see you trying. I know that I may seem rather stern about it all at times, but I'm just trying to get you doing something other than fighting with yourself, because all that seems to do is leave you exhausted."

I blinked rapidly in response, furiously trying to keep from crying. I picked up my coffee mug to give my hands something to do. He doesn't think I'm failing, he doesn't think I'm failing, he doesn't think- but I could be doing more. 
“See, there you go again, you're brain whirring away. I can tell there's something troubling you, but I can't always be sure about what. Is it going back to school? Is it meam I putting too much pressure on you? I can't tell if you just continue to stew all by yourself, sweetie."

I let out a breath, counting to eight. "No that's-I'm. I just wanted to know what you thought. And you're right, I have been fighting with myself."

"See, maybe that's something to talk with Laurel about — again with that face. I do think that she's capable at her job, you know, I just wonder if she's the right fit for you."

"She is. I really feel like I can make more progress with her."

His clap startled me, interrupting the relative quiet of the kitchen. "Well then, there you have it. Come on, you need to eat before school."

Allowing myself a small smile, I turned back to the kitchen counter. The thought of facing all of the expectations that were tied to my last term of high school was frightening, and made my stomach churn. But that was okay-I wouldn't be alone, Cassidy would be there too. Mom and dad supported me in their own ways. I wasn't alone. It was a simple thought, but it rattled around in my mind as I sipped my coffee, refusing to be ignored. Warmth spread throughout me, and I knew it was from more than just the drink. Breathe in. Breathe out. It was time to start the day. 


\section{Creative Thesis Scholarly Reflection}

My focus for my thesis project was to examine how mental health issues are depicted within Young Adult literature, specifically through first person narration. My research on this topic was broad in regards to the different mental health issues that English scholars such as Amanda Thein, Mark Sulzer, Alison Monagha, and Anastasia Wickham were most concerned with discussing, and looked at authors and scholars that discussed disorders such as depression, schizophrenia, and even eating disorders. My main concern throughout my research, however, was to see how other writers aimed to depict mental health issues authentically, and in a conscious manner, rather than relying on stereotypes of mental illness that have been produced by the media. Each of these areas of concern and focus is reflected in my research question that guided my research, which was: How can authors de-stigmatize mental health in Young Adult literature through first person perspective narration? This line of query has helped me with not only finding a focus for my research, but also with writing a short story titled "Quiet Dissonance" in response to my research findings, taking it upon myself to try and depict the very mental health issues I was reading about being depicted within the Young Adult (YA) genre. I was able to best accomplish this through the use of first person narration. Using first person narration enabled me to more clearly demonstrate the internal struggles and hardships of having 
a mental illness, helping me to make my writing more authentic and truthful to my own

experiences with anxiety and depression.

Scholars such as Alison Monaghan and Catherine S. Ross work to answer the question of how to depict mental health issues authentically by closely analyzing different YA literature.

Monaghan does her analysis by focusing on the novels The Perks of Being a Wallflower by Steven Chbosky and Asylum by Madeleine Roux in "Evaluating Representations of Mental Health in Young Adult Fiction.” While Monaghan praises The Perks of Being a Wallflower for its depictions of mental health, she raises concerns with Asylum for using stereotypical horror movie tropes when describing mental health institutions. This tells me that scholars like Monaghan are specifically looking at the descriptions regarding not just mental disorders within YA literature in order to determine what is and what is not harmful writing, but they are focusing on descriptions of all issues related to mental health, such as mental institutions as well. In fact, scholars such as Catherine Ross go so far as to analyze the "literary formulas" that are used within the YA genre in her article "Young Adult Realism: Conventions, Narrators, and Readers," arguing that YA novels use archetypal story patterns to form their narratives, such as coming of age stories or a heroic tale of battling monsters (Ross 176). Furthermore, Ross argues that these archetypal patterns are often drawn from specific cultural themes, which is what brings realism into the YA fiction genre (177). This brings up the issue of one's readers being able to relate to 
the author's work, meaning that the author should strive to write consciously about such difficult topics such as depression and suicide. Scholarly work such as Ross's has made me hyper aware of my own descriptions and patterns that I used when writing my short story "Quiet Dissonance" as I tried to realistically depict living with anxiety and depression rather than rely heavily upon cultural tropes.

Douglas Fisher and Kia Jane Richmond are scholars who also place emphasis upon young adults being able to relate to issues of mental health depicted within YA novels. In his article "The Literary Educator's Role in Suicide Prevention," Fisher's approach differs from Monaghan's and Ross' by encouraging students to create a direct dialogue with the literature they are reading, both through their own writing and their class discussions (Fisher 369). This promotion of student engagement with dark subject matters within YA literature is a reminder to authors that their readers are an active participant with the dialogue of their novels. An example of this engagement that Fisher gives is of one his students responding to the novel Life is Funny by E.R. Frank, which explores subjects such as abuse, rape, and suicide. In response to the novel's characters his student says: "This is a real book. I mean, like these are people I know." Another student of Fisher's wrote a letter to one of the characters, saying "Sonia, I knows how you feel. I lost a friend. He killed hisself" (366). Fisher's students demonstrate the need to be able to connect with literature, to be able to see oneself in the story they are reading —especially 
when that literature is exploring difficult issues that they themselves might be going through, such as having a friend who committed suicide. Richmond also views YA texts that depict mental health issues as a means of teaching empathy. For example, in her article "Using Literature to Confront the Stigma of Mental Illness, Teach Empathy, and Break Stereotypes" Richmond calls for teachers to "expand the canonical literature" in order to make room for more fictional works that depict mental health issues within the YA genre to better help students become more aware of the stigma around mental health issues (Richmond 20). Like Fisher, Richmond promotes creating a dialogue with students via writing poems, keeping journals, and small group discussions (21). When reading Thirteen Reasons Why by Jay Asher, a famous book which depicts suicide, depression, and rape, Richmond's students described Asher's book as “powerful,"due to "its imagery, its presentation of strong characters who are reflective, and its textual complexity" (22). This response from Richmond's students demonstrates how young adults value and relate more to complex characters who think reflectively, rather than characters who seem to have mostly surface level interiority. Once again, emphasis is being placed upon empathetic characters in relation to depicting mental health issues, and the fact that mental health disorders are complex issues that should be treated as such by YA authors.

In response to the emphasis placed upon empathetic and realistic writing in regards to mental health throughout my research, I chose to only depict depression and anxiety disorders 
throughout "Quiet Dissonance." This was a very conscious decision on my part, since I myself suffer from these disorders, and therefore feel that I can genuinely work to de-stigmatize them in my writing. Wickham discusses the issue of writing about issues that you yourself have no personal experience in, stating "If these novels are written exclusively for mentally ill adolescents to read, perhaps they will be perceived as inauthentically voiced. If, on the other hand, they are for the broader population, the characters' voices might engender understanding regardless of authorial authenticity." (Wickham 15). This statement is worrying, because the people who actually experience what you are writing about should in some way be able to relate to the characters you are writing. An author should be able to educate the public on issues of mental health, while also simultaneously being able to depict these issues authentically. Otherwise, I do not believe that you can say as a writer that you have done your best in working to de-stigmatize these issues, because you have then compromised the integrity of your depictions of mental health issues. For instance Monaghan has "markers" that she has created for authors to use when trying to authentically depict mental illness, and one of these markers are:

“The protagonist's/narrator's illness experiences allows the reader to draw parallels between her life experiences and those represented in the narrative" (Monaghan 39). This marker from Monaghan has been my line of reasoning for choosing to only depict and write about mental disorders that I myself suffer from, so that I can work to de-stigmatize them as authentically as 
possible by not romanticizing the very issues I am trying to humanize. An example of this is when I write: "My head felt like a balloon as I desperately counted the time. Four seconds. Seven seconds. Eight seconds. In. Hold. Out. In. Hold. Out." Here, I am describing the protagonist performing breathing exercises - the very same breathing exercises that I myself have used to calm my own breathing when having a panic attack. This is not to say that I believe that authors should completely limit themselves to only writing about what they themselves have experienced, but rather that when it comes to depicting complex issues such as mental health, it is important to be well informed about these issues. Because of this, it is once again important to do research about such issues, and to position your work in relation to other authorial work, if not scholarly, that has already been done before you, regardless of your own personal experience on the matter.

Another marker that Monaghan discusses in regards to writing about mental health focuses on the transparency of the author (39). This marker states: "Somewhere in the narrative, the illness or condition is explicitly articulated" (39). This statement is important to keep in mind when writing about any mental illness because it is important not to deceive your readers in regards to the mental illness you are writing. A writer cannot truly represent the mental health conditions they are writing about if their readers are not even entirely sure of what it is they are trying to depict in the first place. These concerns of writing with transparency is what prompted 
me to open my story with a do-list for the protagonist, who notes in the very first sentence of the story that she has already taken her medication for the day, indicating from the very start that there is something that she needs to take medication daily for. I later come back to the topic of her medication when she returns to her room that very same evening: "My anxiety and depression meds stared at me accusingly from my nightstand, and I rolled over towards the wall, admitting defeat." Here, I am fully disclosing to my readers what disorders I will be depicting throughout "Quiet Dissonance," and that the protagonist views her medication as a direct representation of her mental illnesses. Including these kinds of details in regards to depicting mental illness has helped me to work towards de-stigmatizing anxiety and depression in my writing, since I am being completely transparent with my readers.

Like Monaghan, I have created my own marker for depicting mental illness by consciously choosing to write through the perspective of first person narration. I have chosen this point of view as a lens to portray what it feels like to live with anxiety and depression because first person perspective gives the readers a better understanding of the thought processes of the characters. Thein and Sulzer look to Mike Cadden, an English professor and scholar, on the subject of first person narration in YA literature, who states that "the first person narration that predominates in Young Adult literature can intensify the power of dominant discourses of adolescence in Young Adult literature because such narration feels both authentic in its intimacy 
and — on the surface — offers only a single, dominant perspective on the adolescent experience" (Thein and Sulzer 47). Here, Cadden is emphasizing the intimacy of first person narration, which is an aspect of the first person point of view (POV) that I aimed to utilize when describing my protagonist's inner struggles with her mental health. For instance, using first person POV has enabled me to better demonstrate the inner turmoil that inevitably comes with living with anxiety and depression. An example of this is when I describe my protagonist, Ashlyn, getting out of the shower, realizing that she had forgotten to take her medication that day, and her thought process starts to slowly devolve: "It was such a little, easy thing — as easy as remembering to eat. Control was quickly slipping through my fingers day by day, each accomplishment being blotted out by twice as many blunders. I was fine. I could do this. It was still just break-I could get myself together before school started again. I was fine- this was fine- wasn't fine- I'm not fine." Here, Ashlyn's thoughts are clearly devolving as her anxiety continues to grow, which is how I myself have often felt when struggling with my own anxiety. First person narration has allowed me to illustrate the slippery slope that is navigating one's anxiety if you have anxiety disorder, something that would have been much harder for me to do in third person.

While writing “Quiet Dissonance," I have also been aware of what society’s current perceptions of mental health issues are, which I have tried to reflect in how Ashlyn views her own mental illness in relation to all of the able-minded people around her. Thein and Sulzer have 
created a heuristic, describing the relationship between the narrator, the implied reader, and the narratee. Thein and Sulzer describe the implied reader as "a textually constructed reader who observes, appreciates, understands, and is compelled by the interaction between narrator and narratee," whereas the narratee is "the often-invisible character in a text who to whom the narrator talks, writes or references" (48). Thein and Sulzer are clearly trying to demonstrate the complicated relationship between the narrator, who the narrator assumes is listening to their story, and the implied reader that then observes this interaction between narrator and narratee. This was a heuristic that informed my writing for this project, especially whenever I brought up the issue of what is deemed "normal" by society throughout "Quiet Dissonance." For example, when Ashlyn arrives for her therapy session, she thinks: "Of course, I knew that going to therapy wasn't anything new, lots of people did it, but somehow it always felt like I was alerting everyone around me with a public service announcement that 'My brain is different! Not normal! In need of a doctor! Help wanted!'” Here, I am trying to acknowledge through my narrator that my audience is most likely able-minded, as Ashlyn internalizes the messages that society has fed to her about mental health issues being an "abnormal" experience. It is the implied reader that I aim to keep in mind when I then work to establish Ashlyn's journey of de-stigmatizing mental illness for herself, helping her to better cope with her anxiety and depression. Therefore, it was 
important to me to not just merely depict anxiety and depression in my story, but also to illustrate the internal struggles that come from society's stigmatizing of mental illness as well.

My main aim for this project has been to work to further de-stigmatize mental health issues within young adult literature. I have used different tools to do this, such as utilizing first person POV, relying upon heuristics, as well as my own personal experiences regarding struggling with anxiety and depression. This project is by no means meant to be an isolated effort, but rather I hope to have written a short story that responds to and is in direct dialogue with the scholars that I have researched. If anything should be taken away from this project, it is that authors within the young adult genre should strive to write authentically when depicting disorders and issues regarding mental illness, so that disorders can continue to be humanized within literature, rather than viewed and depicted as being Other. 


\section{Works Cited}

Fisher, Douglas. “The Literacy Educator's Role in Suicide Prevention.” Journal of Adolescent \& Adult Literacy, vol. 48, no. 5, 2005.

Monaghan, Alison. "Evaluating Representations of Mental Health in Young Adult Fiction: The Case of Stephen Chbosky's The Perks Of Being a Wallflower." Enthymema, no. 16, 2016.

Richmond, Kia Jane. "Using Literature to Confront the Stigma of Mental Illness, Teach Empathy, and Break Stereotypes.” Language Arts Journal of Michigan, vol. 30, no. $1,2014$.

Ross, Catherine S. "Young Adult Realism: Conventions, Narrators, and Readers." The Library Quarterly: Information, Community, Policy, vol. 55, no. 2, 1985. Thein, A.H., \& Sulzer, M.A. "Illuminating Discourses of Youth Through the Study of First-Person Narration in Young Adult Literature.” English Journal, no. 104, vol. $3,2015$.

Wickham, Anastasia. "It is All in Your Head: Mental Illness in Young Adult Literature." The Journal of Popular Culture, vol. 51, no. 1, 2018. 